\title{
Temporal dimensions in Notes on Manuscripts and Old Books in Moldavia, I-IV, a corpus edited by I. Caproșu and E. Chiaburu
}

\author{
Maria Lupu* \\ Faculty of Letters, "Alexandru Ioan Cuza" University, Bd. Carol I 11, 700506 Iași, Romania
}

\section{Article info}

History:

Received December 7, 2016

Accepted January 1, 2017

Published March 23, 2017

Key words:

notes on manuscripts

history

culture

mentality

\begin{abstract}
This article is part of a broader research regarding the evolution of mentalities in the period starting with the $16^{\text {th }}$ century, the aim of the present research being to identify and discuss the ways in which people in those days perceived time.

Our research focused on the material provided by the marginal noteswith a value of their own-made by readers on the pages of manuscripts from Moldavia over the span of more than 400 years. The main instruments we have employed are analysis and synthesis, from a diachronic perspective, from particular to general, by means of the inductive method.

As a result, an image has been shaped of the means by which the event, as an element of time, was perceived and rendered, and of the way in which time becomes the fundamental landmark of life, the one that comprises, marks, and generates the entire reality.
\end{abstract}

\section{Introduction}

Most of the books that have been read in the Romanian Countries comprise, along with the text itself, hundreds of notes on the white sheets in the beginning or in the end of the book, on the sheets that serve to the binding of the volume, on the margins of the pages or, most often, at the end of the text. The tomes of documents edited by the historians from Iași cover a long period, starting with the $13^{\text {th }}$ of March 1429 until the Small Union, in 1859; the material they make available is rich, heterogeneous and extremely interesting, which acquires an independent value and becomes a distinct literature providing a fresco of a bygone age.

The multidisciplinary nature of the old notes makes them real sources (which are unique in their specificity) for the research in various fields, for the knowledge of the Romanian history, culture and language. This very wide range of semi-anonymous chronicles recomposes an image of the mental universe of the Romanian society in the former centuries. Either they record the trying of the pen, the owner, the donation, personal information, natural phenomena or historical events etc., many notes are dated, assuming thus a temporal dimension. Time experience is one of the relevant landmarks likely to develop the basic mental frames of a society, of a culture, depicting the way of thinking and living in a society (Nicoară, 1997, p. 54). Thus, the perception of time in the marginal notes is particularly relevant in the attempt to define some specific mental structures.

\section{The book as a dimension of time}

A debate on time experience as it is reflected in the marginal notes should start with the book itself, followed by the marginal note. Extremely valuable, the book is a dimension of eternity since the $15^{\text {th }}$ century throughout the whole studied period. In a society where, up to a point, the orality rules, the writing becomes, as in Phædrus' myth, a cure of forgetfulness and of ignorance (Platon, 2011, p. 126). Due to the Christian message it contains, the books enjoy a special moral consideration and there is the

*Email address: marioaralupu@yahoo.com. 
Maria Lupu

belief that the volume / manuscript is intended for an eternal existence (Chiperi, 1996, p. 13). Once assigned to books and fixed by writing, this certainty stimulates the notes, which become a connection with posterity, facing time by looking for a collocutor in future generations; hence the motif in the most marginal notes, "(in order) to be known".

Related to the dimension time, the book reveals a deeply religious feeling of the people of that time, outlining, through its depiction in the perception of community, a temporal dimension in the Christian sense (Radosav, 1997, p. 75). The time of the book is eternity itself: "Stăpîna și cneaghina Theodora" [The Mistress Theodora] gave a Gospel to the Metropolitan Church of Suceava "neclintit în vecii vecilor, amin" [firm both now and ever, amen] $(\mathrm{I}, 24)^{1}$. Once put in the lectern or in the temple, the worship book becomes immovable, escaping the trace of time (Ofrim, 2001, p. 129). In the middle of the $16^{\text {th }}$ century, the metropolitan Teofan donates a book "ca să-i fie lui amintire pentru nesfîrșiții veci" [to be for his memory into the ages] (I, 57). Sometimes, the time of the book is perceived as being perfectly equivalent to the eschatological time, the time of the book being the time of God's world (Radosav, 1997, p. 76). Thus, the monk Parthenie from the monastery Bisericani buys the Psalter "ca să fie în chilia mea, pînă cînd va milui Dumnezeu în această lume deșartă” [in order to be in my cell until God shows his grace in this vain world] $(\mathrm{I}, 157)$. The book donation is not the only contract made for eternity. More terrestrial acts, such as selling the book, may also be done "în veace de vece" [forever and ever] (I, 401). Because the book is considered to be "vecinică pomenire" [everlasting commemoration] for the donors' souls (II, 30), it is seen as the "key" to the world of eternal happiness, a link between the mundane and the divine: those who have contributed to the acquisition of a Chiriacodromion [an Orthodox worship book] are "scriși pi patruzăci di fili, spre pomenirea lor și a tot neamul lor, în veacul acesta și în celalalt ce va să fie” [written on forty sheets, for their and all their followers commemoration both now and ever] (III, 126). Thus, the book is integrated into the complex of beliefs, of traditional customs meant to ensure the salvation of the soul and it is a way of strengthening the solidarity of the world of living and the ancestors' world (Ofrim, 2001, p. 131). The book spans over generations, being bought "ca să fie odoru în veci feciorilor mei și nepoțîlor și strănepoțîlor" [in order to be forever a treasure for my sons and my grandsons and my great grandsons] (II, 304), with the confidence that it will benefit the same appreciation. The book remains invariable over time, keeping the same features in the $19^{\text {th }}$ century as well, being an "vecinic odor de fericire" [eternal treasure of happiness] (III, 596), contributing to the "nemuritoare neuitare" [immortal remembrance] (III, 547) of the copyist's name, but also to "iertarea vecinică" [eternal forgiveness] (IV, 453).

The marginal note is another temporal dimension. The act of writing is the symbol of eternity. Being always opposed to the human ephemeral essence, a tension appears between "mîna de țărînă" [the hand of dust] (a synecdoche for the frailty of human nature in general) and "slova veșnică" [the everlasting word] within the marginal notes: "Și mîna care au scris va putrezi în groapă, iar cuvintele vor rămînea în veci, amin" [And the hand that wrote would rot in grave and the words would stay forever, amen] (II, 222). The priest Vasile Baltag writes the holder’s name "spre pomenirii și spre ținere de minte, că oamenii să pitrec, dar sfintele cărți rămîn" [for commemoration, because the existence of the people is temporary, but the holy books stay forever] (IV, 392). The act of writing can also be used to the detriment of the sinners. Thus, in a poem about meditation on death of the late $18^{\text {th }}$ century, the sins can be neither "dosnicite" [hidden] nor denied, because they "sînt scrise prin izvoade/ [...] Să rămîi în vecii” [are registered / [...] in order to be remembered forever] (II, 319).

\footnotetext{
${ }^{1}$ Due to their frequency, the references to Notes on Manuscripts and Old Books in Moldavia will be marked as follows: within round brackets we will give the volume number with Roman numerals, followed by the page number with Arabic numerals.
} 


\section{Simultaneity}

Most of the time, the marginal notes enable the author's memory; subsequent to the event, the notes lie at the crossing of what the Greek called mnème (remembrance that occurs as a feeling) and anamnèsis (the remembrance as the object of an active search) (Ricœur, 2001, p. 34). The events, which are brought up to date by their marginal recording, are, most often, dated. According to Aristotle, two dimensions trace the relationship between the memories: simultaneity and succession (Ricœur, 2001, p. 186). The marginal texts rely mostly on the first axis. Although the notes normally include the date-explicit references to the "chronic time" under which they fall-further indications to describe more precisely the time of the event are very common. There is a constant concern to trace certain limits on the time axis.

The coincidence of the recorded event with other social, historical, political, natural or personal happenings is linguistically rendered through various phrases and structures, adverbial most of the time, all synonymous with while: "during", "at the time of", "in the days of", "during the time of", "during the reign of", "while", "then" / "at that time", the time preposition "under" / "during"; the simultaneity is also expressed by verbal categories of duration: gerund (being) or structures with the imperfect "era" (past continuous, was ...-ing). The succession on the time axis is expressed by "after" or "afterwards". Additional information on co-dating past events are actually the same as the events themselves, those which cause the note itself: the reign, all kind of social-political situations, natural phenomena or personal data. Everything is likely to become a temporal anchor.

\section{Temporal background}

From the earliest marginal notes there is a certain structure that provides consistency of a political reigning background, consistently used thereafter: "in the days of", followed by the title of the contemporary voivode. If in 1429 a Gospel (Tetraevanghel) "s-a lucrat [...] în zilele binecinstitorului şi de Hristos iubitorului domn Io Alexandru voievod" [was made in the days of honest and pious Alexandru] (I, 1), four centuries later another Gospel is written by "smeritul ieromonah Irinarh [...] în zilele binecredinciosului și de H(risto)s iubitorului domnului nostru Io Ioann Sandu Sturza boieriu" [the humble monk Irinarh, in the days of the pious and Christ loving our voivode, the boyar Ioann Sandu Sturza] (III, 600). The reign, which is used almost as a rule in the dating of the marginal notes especially until the second half of the $18^{\text {th }}$ century loses ground, becoming, at the beginning of the following century, an exception, without, however, completely disappearing. One possible explanation could be that, in early marginal notes, when writing was not a common activity for anybody, it was mostly linked to state institution - chancellors, clerks, these referring invariably to the ruler; later, when the books, the lettered and the marginal notes become more numerous, the authors, belonging to various social layers, no longer relate to the throne. In the studied texts the state becomes a temporal expression personified by a monarch (Barbu, 1996, p. 24). Being a stability symbol, the voivode makes the time more concrete, more visible. All the same time, the state official seems in possession of a certain time segment: Teofilact monk buys and donates Palia "pe timpul binecinstitorului domn Ioan voievod" [in the days of the honest voivode Ioan] (I, 63). As a reference point for dating the reign is not regarded as an amorphous situation, but in its dynamics: the coming to the throne, the dismissal etc. Thus it outlines an entire political background marked by frequent reign changes, by the reccurence of the same ruler: chancellor Vaile wrote in 1726, "în zilele preluminatului și înălțatului domnu Io Mihai Racovițî voievoda, în al unsprăzecele an a înălțatii domnii, la a triia domnie a mării sale" [in the days of the enlighted and famous Mihai Racoviță voivode, in his eleventh year of his reign, in his third reign] (I, 437).

\section{Temporal references}

Military and political events (wars, robbery raids, foreign occupancies), socio-political agitations, the territorial changes, the system of foreign domination (Chiperi, 1996, p. 51), etc. are also used as a time 
reference in the marginal notes. It is thus created a truthful socio-political background, throbbing with life. Concurrency is indicated by all kind of situations that put a mark on the collective sensibility. An April Minei is written and donated in 1574, "cîndu au venit păgînii turci și tătari și au omorît pe Ion voievod și pe toți ostaşii lui și au cucerit Țara Moldovei mai mult de jumătate” [when the pagan Turks and the Tartars came and killed the voivode Ion and other soldiers and conquered more than half of Moldavia] (I, 85). "Vremurile nepaşnice" [the troubled times] (I, 307) vibrate with robberies, enslavings and murders. A Liturghier [Missal] is written "cînd au ars țara și au robit turcii și tătarii" [when the Turks burned the country and the Turks and the Tartars enslaved people] (I, 257); weapons are heard in the background in the frequent wars between great empires that were taken in the Romanian area: "Rînduiala călugăririi" is "tălmăcită și scrisă” [translated and written], amongst others, "în vreamea răzmiriței, nepăcii și al războiului împărăției Rossiei cu împărăția Turcului pentru Țara Leșască și pentru Moldovlahie i proci” [in the time of rebellion, revolt and war between Russia, Turkey and Poland for Moldavia] (I, 198). References to foreign occupancies, to comings and goings of foreign armies are increasing in the second half of the $18^{\text {th }}$ century. A Gospel is purchased in 1771, "în zili(le) moscalilor" [during the days of the Russians] (II, 201), the Solca monastery owns at 1776 a Carte românească de învățătură [Romanian book of doctrine], "fiind nemții stăpînitori pe aice" [while the Germans rule] (II, 251); and in 1788, when "în Moldova era oasti moschicească" [there was a Russian army in Moldavia], "întîie noastră fiică, Todosia" [our first daughter, Todosia] was born (II, 471). Most personal events are put down on the margins of the books at the pace of peace conventions or of European wars; the parents' death is put into a context: "Tot la acest an 1812, în luna lui avgust, au făcut pace moscalii cu turcii și s-au întorsu desp(r)e Dunăre înapoi și s-au întors în Țara Moschicească, avîndu bătelia cu Bunăpartă, anumi împăratul franțuzesc sau Napolnun (sic!)” [also in this year 1812, August, the Russians and the Turks made peace and they returned in Russia, fighting with Bonaparte, the French emperor or Napoleon] (III, 302). The details and the extensive space given to such information makes us wonder what is the actually topic of the marginal note. There are numerous examples in this direction. Each political fact of greater or lesser importance has echoed in the marginal notes. Thus, from the data provided as temporal references, it can be imagined a picture full of substance of the historical and political atmosphere in the Moldavia of those times.

Not only political events constitute the time reference. Everything that, in one way or another, marks the human sensitivity can become e reference element. Most peculiar natural phenomena (cruel winters and dry summers, heavy rains or, on the contrary, drought, strong earthquakes, eclipses or other astronomical phenomena etc.) are also considered temporal landmarks. Epidemics also become time frames for the contemporary consciousness: “Să să știe că acestu sf( $(\hat{\imath}) n t$ Minei este a cucernicului ier(o)monahi Ghedeon ot Suvija [...]. Și l-amu cumpăratu în zile(le) preluminatului Ioan Costandin Necolai vodă, cîndu au fost cutremuru mari, cîndu au căzutu mănăstirile după cutremur, ciumă mare. Umbla anul 7246. Eu, monah Ghedeon." [In order to be known that this holy book belongs to the reverend Ghedeon from Suvija [...]. And I have bought it in the days of allglorious Ioan Costandin Necolai voivode, when there was a great earthquake, when monasteries tumbled down after the earthquake, great plague. It was 7246 . I, Ghedeon, wrote here.] (I, 484).

\section{Values of time}

In fact, all the contexts mentioned above represent additional information to what $\mathrm{E}$. Benveniste called the axis of "chronic time". Either the founding event which defines the time axis refers to the creation of the world (by God) or to the embodiment of Christ, time is still "Christianized" by church, monopolized by calendar, the reference point being a biblical one (Nicoară, 1997, p. 60). For a long time marginal notes are dated in the biblical chronology, where the history of humanity begins with Adam: "Anul $6939<1431>$ martie 24, am sfirșit" [It was the $24^{\text {th }}$ of March $6939<1431>$ when I finished] (I, 1). In the Moldavian world as it is reflected in the marginal notes is still used the old Julian calendar, the chronological system using both landmarks from the middle of the $18^{\text {th }}$ century: both from the creation of the world and the 
birth of Christ. A Liturghie [Mass] is purchased "în anul de la facerea lumii 7158, iar de la nașterea trupească a Domnului Dumnezeu și Mîntuitorului nostru Iisus Hristos 1659" [in the year 7158 from the creation of the world and 1659 from the birth of the Lord and Saviour Jesus Christ] (I, 228). This linear and implacable vision of time is specific to Christianity. There are three essential moments on this axis: creation of the world, the embodiment of God and the Doomsday. As an objective duration, time flows continually into eternity. Named by the Romanians with a touch of mysticism veac [century/age], it includes both historical time and eternity (Bernea, 1997, p. 147). The two sides of the time, the moment and the eternity, are both to be found in the plural "nesfirșiţii veci" [endless centuries] (I, 56), "veacuri fără de sfîrșit" [to the end of times] (I, 75). The marginal notes show a constant vision of a time which is no more than an affluent of the eternity; a certain clerk called Stephen, who wrote a Gospel in 1579 utters both a curse and a blessing, valid "în acest veac și în cel viitor" [in this century and the next; to the end of time] (I, 94); two centuries later it is invoked the praying for “îndurători ai cărții” „în veacul acesta şi în celalalt ce va să fie" [those who have bought the book... into this world and the other that will be] (III, 126). Explicitly for the Christian vision of time is a marginal note from 1780, a lyrical meditation on death. Used in singular form, veacul [the age] is history marked, becoming "acest veac" [this age]: "Veacul, lumea să sfîrșaște, județul să găteaște” [the age, the world ends, the doomsday will come] (II, 320). Placed between these two moments, the Creation and the Day of Judgment, time flows continually, updating, with every human life, however, the possibility of eternity: "Acolo iasti vesălia ce nespusă / și lumina ce nestrănsă, / unde nu poate nime să privască / și să nu să vesălească / la atîta vesălie / să să dezmierde în vecie" [At that place there is the unspeakable joy / and the burning light / where nobody can see / and not be glad / to see such joy / to be delighted forever] (II, 320). Therefore, in the marginal notes, the form veci [forever], and the adverbial phrase that derives from it, pe veci (e) [to the end of time], mean the whole time, past, present, future and something else, the eternity after the abolition of the temporal dimension of the world; in the singular, there is acest veac [this life] and celalalt veac [the other life, the afterlife] sau ce va să vie [the life that should come], the former meaning this world/life, and the latter the world beyond which divides, in the Christian imagery, into hell and heaven. Nevertheless, veacul is opposed to the time, days, synecdoche of a fragmented and ephemeral time, usually attached to a name of a voivode or a bishop who symbolizes, at a high level, however, the implacable passage of time: in zilele [in the days of ], in vremea [in the age of ], or even in domnia [during the reign of ], in timpul [in the time of].

During the four centuries we constantly observe the striving for accuracy of the marginal notes' authors. The recorded event is spotted in time very precisely. The first marginal notes sometimes add to the year also the month and the day: a Tetraevanghel is begun on "aprilie 6 zile" [the $6^{\text {th }}$ of April] and ended "al 2-lea an, [...] februarie 3 zile, in anul 6944<1436>" [the next year, on the $3^{\text {rd }}$ of February, in the year $69441436>$ ] (I, 2). Sometimes the time expression is astronomically accurate: the deacon Ion copies out another Tetraevanghel "în anul $7050<1541>$, luna noiemvrie 23 zile. Era atunci crugul soarelui 22, al lunii 1 , numărul de aur 4, temelia 14 , epacta 6 " [in 1541, the $23^{\text {rd }}$ of November. It was the the solar cycle 22] $(\mathrm{I}, 55)$. A new representation of time using the clock begins in the marginal notes with the middle of the $16^{\text {th }}$ century, when the copying of a manscript "s-a început în luna septembrie 21 și s-a sfîrșit în luna mai 21 zile, fiind vineri ora 13; vineri s-a și început, la întîiul ceas din zi" [was started on the $21^{\text {st }}$ of September and was finished on the $21^{\text {st }}$ of May, at one o clock, on Friday; on Friday the manuscript was begun and on Friday was finished] $(\mathrm{I}, 61)$. Sporadically noted until the late $18^{\text {th }}$ century, starting with the $9^{\text {th }}$ decade of this century and the beginning of the next century the specifying of the hour becomes almost constant. The notes that record natural phenomena mostly enjoy this "privilege”: "Să să știe că la anul 1805 iunie 29, sara la 2 ceasuri de noapte s-au întunecat lumina lunii, fiind întunecare, pînă la 3 ciasuri și giomătate" [Let it be known that in 1805 , on the $29^{\text {th }}$ of June, in the evening, at two oclock, the light of the moon darkened until half past three] (III, 191) and "la anul 1831 ghenarie 11 zile, marți noapte spre miercuri la nouă ceasuri fără 20 minute evropenești sau sau 4 ceasuri și 8 minute turcești, s-au cutremurat pămîntul” [in 1831, the $11^{\text {th }}$ of January, Tuesday night to Wednesday at twenty minutes to nine by European clock or eight minutes past four by Turkish clock the earth shook] (IV, 37). 
Time also gains more accuracy in other situations as well. The eye looks for a hour hand also in intense moments, births of children or, on the contrary, deaths. Thus, on the $16^{\text {th }}$ of July 1797 "s-a născut fiul mieu Nicolae, joi la 12 ceasuri și 21 minute ziua" [my son Nicolae was born on Thursday, at twenty-one minutes past twelve during the day] (III, 116), and the priest Ștefan from Sauceniță "au murit [...] la velet 1819, mai, în joi noapti, spre viniri, la 6 ceasuri” [died in 1819, on May, Thursday night to Friday, at six o'clock] (III, 451). It would seem that these extreme events, assigned to the rites of passage, are felt acutely under time pressure - a beginning, in the first case, and an end in the second. Ever since the birth, the human being is placed, though, under the auspices of concrete, objective, ruthless time, and at the final moment, beyond this world, transcends its devouring temporality. The individual adventure consumes between two clear markers, the hour hinting at frailty and brevity of life.

But marginal notes also contain at least one situation where is used the time precision, namely the finishing of the manuscript: "Să se știe că am prescris-o eu, cu slova me, [...] şi luănd sfîrşit în anul 1807 iul(ie) 17, la 12 ceasuri din zi" [Let it be known that I have written out myself, with my own hand, [...] and I finished it on the $17^{\text {th }}$ of July, at 12 o'clock in the day] (III, 226). This would integrate itself within a time of labour (intellectual time, in this case), an individual time. Work transcends the medievalist conception according to which it is a remedy against idleness and against innumerable temptations. Time starts to be a preoccupation for those who write on the margin of the leaves. This is proved by marginal notes that emphasize the concern to estimate the hours: "Să să știe cîte ceasuri sînt într-un an: 8760" [In order to be known how many hours are during a year: 8760] (III, 191), or space to time conversion: "[...] De la poalele Bălcanului și pănă la ceialaltă poști iarăși opt ceasuri, însă 2 suișul, 2 mergere pe podiș, 2 coborîșul și 2 păn-la poști de acole; de la poști apoi și pîn-la Țarigrad mai sînt 9 poști mari, cîte de 12 ceasuri. [...]” [From the foot of Balkans and to other halt there are 8 hours, 2 the ascent, 2 walking on the plateau, 2 the descent and other 2 until the halt there; from there until T,arigrad there are 9 more haltings, each of 12 hours] (IV, 13). The flow of time is seen on the concrete hour plate (Barbu, 1996, p. 21). Time has gained greater importance in the economy of existence (Lemny, 1990, p. 148), rendered by the zeal with which various social groups relate to the hour. However, the fact that this pattern is not a generalized one in the marginal notes, most of the time references staying in a different style, is illustrative for the slow progress in the mental structures of the vast majority. Even if the entire existence is not changed, its pace was renewed comparing to the previous period (Lemny, 1990, p. 153), being a more rushed one and, therefore, more concerned with how to grasp the exact moment.

Natural time to which the authors of the marginal notes relate is a cyclic one, paced of day and night alternation, of seasons and farming work. Constantly, marginal texts record the exact day and the month of the event: in 1431 "anul 6939 martie am sfirșit" [March 6939 I finished] (I, 1); four centuries later, " 1856 noiemvrie 12 , s-au cutremurat pămîntul, noapte la $2 \frac{1}{2}$ ceasuri" [on the $12^{\text {th }}$ of November 1856 the earth shook, during the night at half past 2] (IV, 505). The time of the day is also grasped very accurate in the marginal notes. The day and night are not uniform, but they are divided into well defined subunits. An earthquake occurs “duminică, dimineața”" [on Sunday morning] (II, 304) „feciorul Iordachi” [son Iordachi] is born „într-o sfîntă marți, pe amiazăzi” [on a holy Tuesday, in the afternoon] (II, 87), a sun eclipse occurs "într-o sfîntă duminecă, prin prînzul cel mare, aproape de namezi" [on a holy Sunday, to luncheon, about noon] (II, 141), a fire occurs “marți după Paști, pe amiazizı̂” [on Tuesday after Easter, at noon] (III, 12), a solar eclipse "au ținut de după prînz pînă seara” [lasted since afternoon until evening] (III, 171), another earthquake occurs "după amiază zi, adică îndisară, după toacă” [in the afternoon, after the vesper bell] (IV, 422), the abbot Ioil dies in 1531 "la miezul nopții spre luni" [midnight to Monday] (I, 48). Sometimes these moments are also subdivided: the birth of daughter Docița occurs "sîmbătă spre duminică, după ce au cîntat cucoșii o dată" [Saturday to Sunday after the roosters sang once] (I, 544). Vasile Praja dies "marți cînd se revîrsa zorile. 1785" [on Tuesday at dawn. 1785] (II, 410), an earthquake occurs "noatea pi la cucoși și la revărsatul zorilor" [when the roosters are singing at daybreak] (IV, 15). Sometimes, time references take into account the human activity in that time of the day: "pe cînd se culcă oamenii" [when people go to bed] (II, 487), ,întru o duminică la vreme de masi” [on a Sunday at lunchtime] (III, 
305), „sara cînd șăd uaminiii (sic!) la masă” [in the evening at dinner time] (IV, 15). Other times, the pace is a vegetal one: "pe vremea trandafirilor" [in the time of (the year when) the roses (bloom)] (III, 454), „pi vremia perjălor” [when the plums are ripe] (IV, 87), or the pace of agricultural work: „vara pe vremea seceri" [in the summer during the harvest] (IV, 36).

Another level of perception of time of the events recorded in marginal notes is a time of celebration. No doubt that the authors of the marginal notes live in a Christian time, marked by holidays such as Nativity and Resurrection, St. George, Holy Archangels Michael and Gabriel, The Annunciation, Pentecost etc. A sacred time par excellence, the holiday is a revealed time, an exit from ordinary temporal duration of the profane time. A reversible time and thus recoverable, always equal to itself, an eternal mythical present, the holiday means the ritual revival of illud tempus, of a mythical and religious event (Eliade, 1992, p. 76). Each celebration reiterates for the Christians the essential milestones in the life of Christ, the Virgin and other many saints (Nicoară, 1997, p. 64) bringing up to life, every time, the same sacred time, identical with the initial moment. Taking into account this economy of Christian time, the days of fasting are also of major importance, becoming a reference point in the adopting of a Christian conduct (Radosav, 1997, p. 221).

We notice that, in the marginal notes, the holidays start being a time reference only at the beginning of the $18^{\text {th }}$ century. Until then it is preferred a more objective time scored by year, day and month, a time depending on the voivode and on the ecclesiastical institution - but at a different level, the man who pastors, at a certain time, the Christians („,̂n zilele lui Petru voievod și ale mitropolitului chir Anastasie al cetății Suceava” [during the days of Petru voivode and of Anastasie, the Bishop of Suceava], I, 90). Once that it starts to be mentioned, the sacred time will represent a pattern for the following notes. Not accidentally, the first marginal note that contains a holiday as a time reference records a death and a burial, under the badge of the "great passage" in the Christian sense: the confessor Sava the Great died on $19^{\text {th }}$ of April 1606 and was buried "în ziua Sfintelor Paști” [on holy Easter Sunday] (I, 137), a symbolic moment for the salvation of Christians; nevertheless, we must not overlook that the environment that "produces" the marginal note is a monastic one. Increasingly more frequently in the following centuries the writing out of the manuscripts, the births and deaths are dated after the holidays in the Christian calendar. Even within this sacred time the time is not the same, but it has special qualities. Therefore, the act of desecration such as robbing a monastery by Cossacks takes place in February 1676 "în a doua săptămînă a Postului" [in the second week of Lent] (I, 280), a book is finished "în Săptămîna 1-a a Postului” [in the first week of Lent] (III, 116), and the father's funeral takes place "în Sf(întul) și Marile Post, în miercure, a triea săptămînă” [in the holy and the great Lent, on Wednesday, the third week] (IV, 414).

Sometimes the recorded events belong to a monastic environment so, naturally, one of the time landmarks is part of the sacred time. Eloquent in this direction is the marginal note of "ierei Moisă" [priest Moise], who „s-a însurat la Vinere Mare, s-a diaconit la Crăciun, s-a preoțit la Florii” [married on Good Friday, became a deacon at Christmas and he took the holy orders at Palm Sunday] (II, 21). The events that are part of people's rites of passage (birth - marriage - death) are also put under the auspices of a Christian time; death of "mamei Măriuța" [Maria’s mother] occurs in "1759, în cîșlele cele mari, cu două săptămîni înainte de Lăsata Săcului de Postul cel Mare” [1759, between the Advent and the Lent, two weeks before the beginning of Lent] (II, 86); psalm reader George is getting married on Sunday, the $17^{\text {th }}$ of September, 1761, "cînd era pominirea Sfintei Mucinițî Euftimia, iară duminica era a 15 după Rusalii”" [when martyr Euftimia was celebrated, the $15^{\text {th }}$ Sunday after Pentecost] (II, 114), and son Manolachi "s-au născutu în luna lui dechemvri 2 zile, la Sfintul Prooroc Avraam" [was born on the $2^{\text {nd }}$ of December, on the holy prophet Avraam] (III, 306).

A careful reading of the marginal notes corpus for detecting the particular features of the temporal references reveals that the texts whose topic are the natural disasters-earthquakes, floods, storms, eclipsesare regularly related to a Christian holiday. Thus, "s-au întunecat soarele joi în doî săptămîni după Sfinţii Apostoli” [the sun darkened on Thursday, two weeks after The Apostles] (I, 556), ,au dat piatra ce mari” [the great hailstorm occurred] in „,a doua săptămînă în postul Sîmpetrului” [the second week of the fast 
Maria Lupu

of Saints Peter and Paul] (II, 58), a fire occurs „în zioa de Sf(înta) Troiță” [in the day of the Holy Trinity] (II, 105), „s-a cutremurat pămîntul la Precuvio(a)sa Paraschiva, adică la Vinirea Mari” [the earth shook on The Paraskeva Holy Day, on Good Friday] (III, 141), „marța, zioa” [on Tuesday, during the day] (III, 143) (the $14^{\text {th }}$ of October was popularly called "Good Friday", even when it fell on another day of the week; Tighiliu, 1997, p. 44).

The marginal notes with a weather topic relate to holidays also because these, besides the metaphysical connotations, were influenced by the seasons, indicating periods of time with specific agrarian or pastoral activities from the rural community (Nicoară, 1997, p. 64), and the bad weather prevented these specific activities. On the other hand, dangerous events (earthquakes) or the frightening astronomical ones (eclipses) are linked to the divine will, hence the dating according to holidays. We note a preference for the time references that are related to the fastings, naturally, in a world in which these intervals of bodily and spiritual purification, of sacrifice, were actually lived this way.

Concluding, the marginal notes reveal most varied temporal values. The cyclic time occurs both in its natural cosmic variant and a recurrent updating of holidays; linear time, marked by a continuous flow between the Genesis and Judgment, the profane-objective time scored by the clock, the Christian sacred time. If we were to apply the Krzysztof Pomian model (Ricœur, 2001, p. 187), these temporal references would fall into the first two ways of viewing time, measured by clocks and calendars: chronometry (referring to long or short cycles of a recurrent time that spins: day, week, month, year (Ricœur, 2001, p. 187) - the date in the marginal notes) and chronology (linear time of the long periods, century, millennium, etc., which is differently perceived than fundamental and founding events, Ricœur, 2001, p. 188).

Further we will discuss the values of the subjective time, how the events are related to each other, how all these temporal (and other) references are accumulated into one and the same marginal note, how the author relates, concentrically, to the group(s) he/she belongs to.

\section{The accumulation of time references}

Whether it is the natural / cyclic cosmic time or the chronically linear one, or a fast time or psychological, deeply subjective time, most often these time anchors of the recorded event are various. The marginal notes reveal throughout the ages a keenness of precision, of providing as many time references as possible in order to grasp the exact time of the event as well as possible; paradoxically, we witness an attempt to elude the natural flow of time for that particular event, to paralyse the recorded event on the time axis, thus making it eternal for the posterity. So, almost all the marginal notes that contain information about the moment of the writing or of the recorded event accumulate various time references creating thus a simultaneity which is characterized, in its turn, by a hierarchy which becomes obvious at a multiple reading of the corpus. With the events defining their position relating to each other we find ourselves in what Krzysztof Pomian called cronography (Ricœur, 2001, p. 188), this being a dating system that can lack the calendar.

Thus, since the end of the $16^{\text {th }}$ century, time references reflect a strongly hierarchical society. The reign and the ecclesiastic are the two institutions most often used in depicting the exact moment. Pahomie monk writes a book "pe vremea mitropolitului întregii Țări a Moldovei, chir Gheorghe, sub egumenul Ghenadie" [in the days of Gheorghe the Metropolitan of Moldavia and under Father Superior Ghenadie] and "sub Ștefan voievod" [in the days of voivode Ștefan] (I, 15). Another time the order proceeds from general to particular, in concentric circles: a Minei is donated to Putna monastery "în zilele binecredinciosului și de Hristos iubitorului domn, Ioan Ștefan voievod, domn al Țării Moldovei, fiul marelui Bogdan voievod, și pe timpul arhimandritului chir Spiridon, în anul $7012<1504>$ [...]. Și era atunci egumen și ieromonah Pahomie" [in the days of the most faithful and Christ-loving lord, voivode Ioan Ștefan, prince of Moldavia, son of the great Bogdan ruler, and during the archimandrite Spiridon, in the year 7012 $<1504>$ [...]. And Pahomie was abbot and hieromonk] (I, 31). Paisie, monk and singer, the one who recorded the donation, relates to two authorities: the royal one prevails, perhaps because the voivode is the donor, and the ecclesiastical one, within which he himself lives. The document lies in objective chronic 
time by the date indication: "luna februarie $25^{\text {" [ }}$ on the $25^{\text {th }}$ of February]. The worldly constituent (the voivode, the nobility) and the ecclesiastical one are reference elements in the defining of time, especially in the marginal notes from the first period, but also in the second half of the $19^{\text {th }}$ century. Sometimes the author puts down the reign and the year, other times the metropolitan / bishop / or other illustrious contemporary clergymen, most often these time anchors are conjugated: voivode, metropolitan and date. Administration and church levels are intertwined, sometimes successively descending on hierarchy: a donation is made "în zilele [...] domnului nostru Vasile voievod, și în zilele episcopului Theofan, și în zilele lui Gavrilaș fost mare logofăt, pe vremea preotului Petrașco Mediaschi, care era în acea vreme la Bîrnova. În anul $7158<1650>$, luna mai, douăsprezece zile" [in the days of [...] our great Vasile voivode, and during the days of bishop Teofan and in the days of ex-chancellor Gavrilaş, when Petraşco Mediaschi was a priest, who was at that time at Bîrnova. In the year $7158<1650>$, on the $12^{\text {th }}$ of May] (I, 229). This way of noting of the date is nearly constant during the $16^{\text {th }}$ and the $17^{\text {th }}$ centuries, and it extends to the $18^{\text {th }}$ and the $19^{\text {th }}$ centuries. Sometimes the marginal note accumulates all the illustrious ecclesiastical persons; the archimandrite Vartolomei transcribes a manuscript "în dzilele pre luminatului [...] Ioan Theodor voievoda, și a preasfințitului chir Gavriil mitropolitul Moldovii [...] și a presfinților episcopi chir Ioanichi Romanschi, chir Dosithei Rădăuțchi, chir Inochenti Hușschi, fiind igumen în mănăstire Putna chir Pahomii[...]" [during the days of the enlightened [...] voivode Ioan Theodor and in the days of His Holliness Metropolitan of Moldavia Gavriil [...] and of the most holy bishops Ioanichi Romanschi, Dosithei Rădăuțchi, Inochenti Hușschi, the abbot in the Putna monastery being Pahomi] (II, 107). Of course, the author of the marginal text, who notes "de cînd am vinit de la mitropolie din Iaș aici în Pobrata" [since I have come here at Pobrata] relates to the world from which he is part of, thus describing the concentric circles: "în zilele mării sale lui Mihail vodî, mitropolit fiind chir Gheorghie, egumen fiind chir Vartolomei. L(ea)t 7231 iuli 15." [during the days of His Highness Mihail voivode, Metropolitan being Gheorghi, abbot being Vartolomei. Year 7231, on the $15^{\text {th }}$ of July] (I, 425).

In the second half of the $17^{\text {th }}$ century it appears, amongst other references, the contextualization of a personal nature. Metropolitan Dosoftei donates a book in "7195, în Striju, fiind în bejenie printre străini din cauza vremurilor nepaşnice" [7195, in Strij, being a fugitive because of the agitated times] (I, 307). The simultaneity of the recorded events with the ones of a personal nature becomes more frequently in the following centuries. An Octoib is purchased by the author of the marginal note "la domnia preînălţatului domnului nostru Io Ioan Theodor voievoda, fiind rînduit cu slujba agiutorinții la Putna, în anul let 7269 $<1761>$ fev(ruarie) 5" [when His Highness Ioan Theodor reigned, when I collected taxes at Putna, in $7269<1761>$ on the $5^{\text {th }}$ of February] (II, 106); an earthquake occurs on the $16^{\text {th }}$ of October 1774 "și cînd s-au cutremurat pămîntul eram în gios cu vădrăritu" [and when the earth shook I was collecting taxes for wine] (II, 228). The reading of a Chronograph is done during the days of Grigore Calimah and of the metropolitan Gavril, in 1768, "și eram preot la sfînta băsărică ce să prăznuiește Sfinții Părinți Athanasiia și Chiril, aice în Iaș” [and I was a priest at the holy church that celebrates Fathers Athanasios and Cyril, here in Iaşi] (II, 176). We also notice the personal information about health: a Synopsis is read "cînd eram la Cretești, în doftorii" [when I was in Cretești, undergoing a medicine cure] (II, 208), a book is bound in 1800, "cînd am fost bolnav la un picior" [when my foot was ill] (III, 53), and the earthquake from the $24^{\text {th }}$ of April 1834 is related to "stricarea stomahului" [a stomac ache] from that day (IV, 96). Sometimes we find out the author's age in some important moments. Manolache Cîrje finished writing out the book on the $20^{\text {th }}$ of November, 1811, in the evening, at " 7 ceasuri de noapte, [...] fiind în vrîstă de 20 de ani" [7 o'clock in the night [...], I was 20 years old] (III, 287), and sometimes the recorded event is only a pretext for giving out personal information. The earthquake from the $6^{\text {th }}$ of February 1812 occurs "cind cetem eu sara, eram cu mătușa și cu mama în casă. Umblu la scănțălarie (sic!) ispravnic amu. Și Gheorghie Liga samiș" [when I was reading in the evening, I was home with my aunt and my mother. I am an office clerk now. And Gheorghie Liga collects taxes] (III, 568).

Historico-political events also associate with other time references. They create a realistic background for the recorded event, providing at the same time substance and the feeling of a truthful moving world. 
Paradoxically, despite the fact that the exact moment is accurately grasped, this seeming to "fix" that particular event on the time axis, immobilizing it, this additional information referring to fights, foreign occupations, rebellions etc. also create a noisy and lively dramatic background. The foreground of the marginal note is accompanied of a dynamic pulsating of life. Unlike the situations in which the voivodes and the metropolitans constituted time references, which induces a static impression, Tartars' robberies, the battles between Turks and Russians, between Turks an Germans, "vreamea răzmiriței, nepăcii și al razboiului" [times of rebellion, fight and war] (II, 198) create a world in progress, filled with life and death. This dramatic setting makes the world that is reflected in the marginal notes to throb, it creates a three-dimensioned picture in which the visual and the auditory coexist synaesthetic, what appears to be immobilized in time being resuscitated. The chancellor Manolachi, son-in-law of the priest Andrei, reads in 1771 Cartea românească de învățătură „pă vreame dea răzmiriță, cînd au venit muscalii ș-au luat Hotinul ș-au venit la Ieș și di la Ieș au mersu de-u bătut turcii la Răbîia și dea acolo o samă dintr-înșii au mersu la Focșani și di la Focșani au mersu de-au bătut toamna Galații [...]” [in times of rebellion, when the Russians came and took the Hotin and they came to Iași and from here they went and they defeated the Turks at Răbiiia and from there some of them went to Focşani and after that they went and they defeated Galați] (II, 202), and the details keep flowing. Other information also contribute to creating an image of a world in which dangers lurk, a world in which insecurity becomes the main feature of the life: the change of the fair day in Cernăuți, in 1772, is a good reason to add "și era staroste la Cernăuț dum(nea)lui paharnicul Imbou și d-lui starostele Ilie Herescu, și era tălhari la ulițe, pîn codri, și făc(e) multă ucidere” [and Imbou boyar and Ilie Herescu were chiefs in Cernăuți, and there were a lot of robbers on the roads and in the woods and they were committing a lot of crimes] (II, 209).

The accumulation of all kinds of data, which help specifying the exact time of the recorded event, sometimes become heterogeneous, various information being juxtaposed. Also, sometimes temporal localization of the event is much wider than the event itself, so we ask ourselves what is more important, what is the actually topic of the marginal note. Rînduiala călugăririi is translated:

- „în zilele binecredincioasei şi singură stăpînitoare a toată Rossie şi Moldovlahiei întîie stăpînitoarei, marei doamnei noastră Imperatriți(i) Ecaterinei Alecsievni(i) [in the days of the pious and the only and first monarch of Russia and Moldavia, our great Empress Ecaterina Alecsievni]

- și a preaiubitului fiului și moștenitoriului ei, binecredinciosului domnului țesarevici și marele cneaz Pavel Petrovici [and of her son and successor, the pious czarevitch and great prince Pavel Petrovici],

- în vreamea răzmiriței, nepăcii și al razboiului împărăției Rossiei cu împărăţia Turcului pentru Țara Leșască și pentru Moldovlahie i proci [during the rebellion, agitation and war between the kingdom of Russia and the kingdom of Turkey for Poland and Moldavia],

- fiind și ciumă mare, mare în țară, la Iași, la Botoșani și al alte locuri [during great plague in the country, in Iași, Botoşani and other counties].

- Iară mitropolit țărăi fiind preosf(i)nția sa chir Gavriil [His Holliness Gavriil was the Metropolitan of the country]

- și episcop Rădăuților preosf(i)nția sa chir Dosithei [and bishop of Rădăuți was Dosithei]” (II, 198). We chose this page layout in order to highlight the multitude of time references, striving for creating an extensive picture, for contextualizing, for providing more data which complete the initial information, showing thus a sample of the author's contemporary world. Natural phenomena are usually grasped with a particular precision, fixed almost every time by the religious calendar, plus a whole range of other time references. With a scientific rigour, it is noted: "Să să știe cîndu s-au cutremuratu pămîntul [In order to be known when the earth shook]

- în cîşligile Crăciunului [between Christmas and Lent],

- iarna [in winter],

- în luna lui ghenar [in the month of January],

- în 11 zili marți sara [on the evening of Tuesday the $11^{\text {th }}$ ]

- ca la 3 ciasuri din noapte, spre miercuri [at 3 o'clock during the night, Tuesday to Wednesday], 
- anul 1838 [in the year 1838],

- fiind domn în pămînt Moldovei măria sa Mihail Grigoriu Sturza voievodul [when His Highness Mihail Sturza was the voivode of Moldavia]

- şi mitropolitul Veniaminu preasfințitu [and His Holliness Veniamin was the metropolitan]

- și episcop Romanului Meletie [and bishop of Roman was Meletie]” (IV, 178).

The concentric circles of time are also placed at another level: the birth of "feciorului Iordachi" [son Iordachi] takes place ,în zilele preluminatului domnului nostru și stăpînitoriu a toată Moldova Ion Teodor voievod, în domnia întăia, în luna lui martie în 23, într-o sfintă marți, pe amiazăzi, în leat $7267<1759>$ ” [during the days of our enlighten lord and sovereign of the whole Moldavia Ion Theodor voivode, during the first reign, on the $23^{\text {rd }}$ of March, on a holy Tuesday, at midday, in $7267<1759>$ ] (II, 87). The objectivity of time is fractured by the qualifier "holy", which puts the entire time reference under the auspices of a religious sensitivity with which we got accustomed to.

At the beginning, marginal notes record time objectively (date, the reign, the Metropolitan). As we move forward, time gets marked affectively and there is an increase in the number of time references. The possibilities of combining of the temporal references are countless. Date, reign, metropolitans, abbots, holidays, fastings, personal events, foreign occupations, wars, rebellions, earthquakes, epidemics etc. all of these are arranged and accumulated for the sake of precision. Creating the impression of simultaneity through the specific marks coordinated copulatively with the conjunction "and", this extraordinary accumulation of time references proves the accuracy with which the authors of the marginal notes hope to overcome, for a moment, the impermanence; the multitude of time references is used for "fixing" a particular event on the time axis, creating thus the (conscious) illusion that the moment is saved. Also, the physical, objective time (year, day, time) is associated with psychological affectionate time (subjective selection of the events to which they relate, grasping of some personal events. For the authors, time is not homogeneous, with the same features, but it has distinct qualities. The individual, the personal time melts into a social time, a time of the common destiny (Bernea, 1997, p. 168). Time is also alive, materialized in various individual or more general events. In the marginal notes time is characterized by a specific materialization, by its capability of becoming various (social, personal) events. Thus, time gains its own individuality, it is not abstract, it emerges from the amorphous objective time and gains a specific quality.

Even at a religious level (be it popular or not), time is not equal to itself. Time is active, it has certain positive or negative qualities (Bernea, 1997, p. 208). Thus, a marginal note contains a sequence of days of certain months: "mart(ie) 4 și 20; apr(il) 3 și 20; mai 6 și 20 [...]" [the $4^{\text {th }}$ of March; the $3^{\text {rd }}$ and $20^{\text {th }}$ of April; the $6^{\text {th }}$ and $20^{\text {th }}$ of May], during which "nu-i bine să facă cineva început ori la ce lucru, că va ave pagubi și întîmplări de pacosti, adică supărări și primejdie în urmare acelui drum sau lucru” [it is no good for anyone to begin or to continue a work, because he will have incidents and other misfortunes, that is troubles and danger during that journey or work] (II, 138). So there are bad hours, the influence of time may result in destructive consequences. On the other hand, the positive, the creative time appears in another marginal note: "însămnari pentru celi 12 viniri ce esti bine să le postiască, să nu mănînce creștinu pești, într-aceli viniri, cum nici altă nimică pînă după svințire soarelui, și își va faci vecernie și pacevernița care îi vor fi de mare folos, și sufletești și trupești” [a note about the 12 Fridays when it is good to fast, neither to eat fish during those Fridays nor to eat anything until the sunset, he will participate at vespers and compline and this will be of great use for soul and body] (III, 474), following the enumeration of the respective Fridays. However, in the Christian world, Friday has positive valences.

\section{Conclusions}

In terms of dating the recorded events, the marginal notes from the corpus edited by Ioan Caproșu și Elena Chiaburu divide into marginal notes that mention temporal details and marginal notes that do not specify the date. The reading of the texts in the first category shows obvious that, sometimes, besides noting the objective date, the author offers all kinds of additional information which become temporal 
anchors for the recorded event. These time references belong to the cyclic, cosmic time, manifested in the day-night alternation and in the seasons succession; a chronic time measured objectively by clocks' hands - sometimes time accuracy becoming a constant value. In the linear and implacable flow of time from the Creation towards Doomsday - the key moments in some marginal notes-sacred time of celebration reiterates, each time, tha same sanctified time in the history of Christianity. The high incidence of "Sfintelor Paști" (the Holy Easter), of Christmas, of the Annunciation, of a multitude of characters from the Christian pantheon, of fastings as time references in dating of the recorded events define a deeply religious mentality. Everything can turn into a temporal landmark: reign, various prelates, historical and political events that have impressed the collective sensitivity, natural phenomena with the same feature, personal, domestic or intimate events etc. Very interesting is the accumulation of (all) these time references, sometimes dating the event being so detailed that exceeds by far the space given to the topic (itself). Accuracy being a constant value in the marginal notes, we witness a assiduous effort to grasp the moment, to go beyond the ephemeral, to save a piece of personal or collective life in the flow of time. The multitude of the time references, the relating to the book as a symbol of perenniality, the very marginal notes on various topics prove this attempt to defeat, somehow, time (although the recurrent motif of the hand of dust, a synecdoche of the human condition as a subject to time and, hence, to death is always there), to immobilize it in a fragment of life, to hand down to posterity a breath of life of the authors of these marginal notes.

\section{Bibliography}

\section{A. Sources}

Insemnări de pe manuscrise și cărți vechi din Țara Moldovei [Notes on Manuscripts and Old Books in Moldavia], corpus edited by Ioan Caproșu and Elena Chiaburu, vol. I-IV, Casa Editorială Demiurg, Iași, 2008-2009.

\section{B. References}

Barbu, D. (1996). Scrisoare pe nisip. Timpul și privirea în civilizația românească a secolului al XVIII-lea, Antet, București, p. 24-121.

Bernea, E. (1997). Spațiu, timp și cauzalitate la poporul român, Humanitas, București, p. 147-208.

Chiperi, M.A. (1996). Vechi însemnări românești ca izvor istoric, Silex, Casă de Editură, Presă și Impresariat, București, p. 13.

Eliade, M. (1992). Sacrul și profanul, translated from French by Rodica Chira, Humanitas, București, p. 76.

Lemny, Șt. (1990). Sensibilitate și istorie în secolul XVIII românesc, Editura Meridiane, București, p. 148-153.

Nicoară, T. (1997). Transilvania la începuturile timpurilor moderne (1600-1800). Societate ruralăși mentalități colective, Presa Universitară Clujeană, p. 54-64.

Ofrim, Al. (2001). Cheia și Psaltirea. Imaginarul cărții în cultura tradițională românească, Editura Paralela 45, p. $129-131$.

Platon (2011). Phaidros, translation by Gabriel Liiceanu, Humanitas, București, p. 126

Radosav, D. (1997). Sentimentul religios la români. O perspectivă istorică (sec. XVII-XX), Editura Dacia, Cluj-Napoca, p. 27131.

Ricœur, P. (2001). Memoria, istoria, uitarea, translation by Ilie Gyurcsik and Margareta Gyurcsik, Editura Amarcord, Timișoara, p. 34-188.

Țighiliu, I. (1997). Societate și mentalitate în Țara Românească și Moldova, secolele XV-XVII, Paideia, București, p. 44. 